\title{
Uji Ketahanan Penyakit Layu Bakteri Secara In Vitro dan Uji Daya Hasil Genotipe Kentang IPB
}

\author{
In Vitro Bacterial Wilt Resistance and Yield Test of IPB Potato Genotypes \\ Rika Sri Rahmawati ${ }^{1}$, Muhamad Syukur ${ }^{2,3}$, dan Awang Maharijaya ${ }^{2,3 *}$ \\ ${ }^{1}$ Program Studi Agronomi dan Hortikultura, Departemen Agronomi dan Hortikultura, Fakultas Pertanian IPB \\ ${ }^{2}$ Departemen Agronomi dan Hortikultura, Fakultas Pertanian, Institut Pertanian Bogor \\ (IPB University), Jl. Meranti, Kampus IPB Darmaga, Bogor 16680, Indonesia \\ ${ }^{3}$ Pusat Kajian Hortikultura Tropika, LPPM IPB. Kampus Baranangsiang IPB. Jl. Pajajaran Bogor
}

Diterima 18 Mei 2021/Disetujui 23 Juli 2021

\begin{abstract}
The consumption of potatoes in Indonesia continues to increase, but not entirely produced within the country. This is because the national potato productivity is still low due to non-adaptive imported cultivars. Breeding cultivars with high yield potential and resistance to bacterial wilt disease is an attempt to increase potato production. This study aimed to determine the level of resistance to bacterial wilt disease in vitro and the yield potential of IPB potato genotypes. The research was carried out in the laboratory of the Center for Tropical Horticulture Studies (PKHT) IPB for disease resistance test and Pangalengan, Bandung Regency for the yield test from January to June 2018. A total of seven test genotypes consisting of PKHT 4, PKHT 6, PKHT 9, PKHT 10, PKHT 12, Intan, and Medians, and two control namely Atlantik and Granola were used in this study. In vitro method by cutting inoculation method on plantlets was used followed by monitoring the incubation period, disease incidence rate, and degree of resistance. The yield test was carried out by comparing plant growth and tuber production in the field. The results showed that PKHT 4 and PKHT 9 genotypes were moderately resistant; better than Atlantic and Granola as check cultivars. The yield test showed that two genotypes had high yield potential, namely PKHT 6 (38.91 ton ha ${ }^{-1}$ ) and PKHT 10 (28.75 ton ha ${ }^{-1}$ ) exceeding Atlantik and Granola as checks.
\end{abstract}

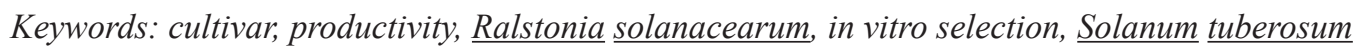

\section{ABSTRAK}

Konsumsi kentang di Indonesia terus meningkat namun belum sepenuhnya diperoleh dari dalam negeri. Hal ini disebabkan produktivitas kentang nasional masih rendah akibat kultivar impor yang tidak adaptif. Perakitan kultivar yang berpotensi hasil tinggi dan tahan penyakit layu bakteri merupakan upaya untuk meningkatkan produksi kentang. Penelitian ini bertujuan untuk mengetahui tingkat ketahanan penyakit layu bakteri secara in vitro dan potensi hasil genotipe kentang IPB. Penelitian dilakukan di laboratorium Pusat Kajian Hortikultura Tropika (PKHT) IPB untuk uji ketahanan penyakit dan di lahan pertanaman kentang milik petani di Pangalengan, Kabupaten Bandung untuk uji daya hasil pada bulan Januari sampai Juni 2018. Sebanyak tujuh genotipe uji yang terdiri dari terdiri dari PKHT 4, PKHT 6, PKHT 9, PKHT 10, PKHT 12, Intan, dan Medians, serta dua pembanding yaitu Atlantik dan Granola digunakan dalam penelitian ini. Uji ketahanan penyakit layu menggunakan metode in vitro dengan cara menginokulasi plantlet dengan metode gunting pucuk dilanjutkan dengan mengamati periode inkubasi, tingkat kejadian penyakit dan derajat ketahanan. Adapun uji daya hasil dilakukan dengan cara membandingkan pertumbuhan tanaman dan produksi umbi di lapangan. Hasil uji ketahanan menunjukkan genotipe PKHT 4 dan PKHT 9 mempunyai tingkat ketahanan, yaitu agak tahan, yang lebih baik dibandingkan Atlantik dan Granola sebagai kultivar pembanding. Uji daya hasil menunjukkan terdapat dua genotipe yang memiliki potensi hasil tinggi yaitu PKHT 6 (38.91 ton ha ${ }^{-1}$ ) PKHT 10 (28.75 ton ha-1) yang melebihi Atlantik dan Granola sebagai pembanding.

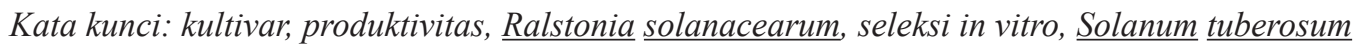

* Penulis untuk korespondensi. e-mail: awangmaharijaya@apps.ipb.ac.id 


\section{PENDAHULUAN}

Kebutuhan kentang belum dapat seluruhnya dipenuhi oleh produksi dalam negeri (Pusdatin, 2020). Impor kentang menjadi salah satu solusi pemenuhan kebutuhan kentang nasional. Impor kentang di Indonesia terus meningkat terutama didominasi oleh kentang olahan seperti kentang beku untuk potato chips, kentang yang diawetkan, pati kentang dan sebagainya. Impor kentang dapat dikurangi dengan meningkatkan produksi kentang dalam negeri dan peningkatan ketersediaan varietas yang cocok untuk kentang olahan.

Ketersediaan bibit kentang bermutu dan varietas yang adaptif menjadi salah satu kendala dalam peningkatan produksi kentang di Indonesia. Kultivar kentang yang paling dikenal petani adalah Granola dan Atlantik yang merupakan varietas introduksi yang masih kurang adaptif di Indonesia. Hal ini ditunjukkan dari masih rendahnya produktivitas kedua kultivar tersebut di Indonesia dibandingkan potensi hasilnya. Potensi hasil dalam deskripsi varietas Granola mencapai 26.5 ton ha $^{-1}$ dan potensi hasil Atlantik berkisar antara 8-20 ton $\mathrm{ha}^{-1}$. Namun kenyataannya produktivitas kentang tahun 2019 baru mencapai 19.27 ton ha ${ }^{-1}$ (Kementan, 2020). Dengan demikian, diperlukan perakitan kultivar unggul baru dengan tingkat adaptasi dan daya hasil yang tinggi. Serangan penyakit juga mempengaruhi rendahnya produksi kentang di Indonesia. Penyakit layu bakteri merupakan salah satu penyakit utama pada tanaman kentang dan menyebabkan kehilangan hasil yang signifikan mencapai 40-100\% (Otieno et al., 2021).

Upaya perakitan kultivar kentang tahan penyakit layu bakteri dan/atau berdaya hasil tinggi perlu dilakukan di Indonesia. Persilangan konvensional kultivar Granola dan Atlantik menghasilkan beberapa genotipe yang memiliki tingkat ketahanan lebih tinggi dari tetua (Purwito dan Wattimena, 2008). Serangkaian penelitian yang dilakukan oleh Pusat Kajian Hortikultura Tropika (PKHT) IPB telah menghasilkan beberapa genotipe harapan seperti PKHT 4, PKHT 6, PKHT 9, dan PKHT 10 yang terindiksai memiliki pertumbuhan dan produksi yang baik (JolandaLaisina et al., 2021; Maharijaya et al., 2020; Maharijaya et al., 2021). Tahapan selanjutnya sebelum menjadi varietas adalah pengujian daya hasil dan keunggulan. Penelitian ini bertujuan untuk menguji genotipe kentang IPB terhadap layu bakteri secara in vitro dan menguji daya hasilnya di lapangan.

\section{BAHAN DAN METODE}

Penelitian dilaksanakan di Laboratorium PKHT IPB, Bogor untuk uji ketahanan penyakit layu bakteri secara in vitro. Pengujian dilakukan pada bulan Januari hingga Maret 2018. Uji daya hasil dilaksanakan di Desa Margamukti, Kecamatan Pangalengan, Kabupaten Bandung. Lahan percobaan memiliki ketinggian $1,800 \mathrm{~m}$ dpl dengan titik koordinat 7¹2'29'LS dan 107'37'48'BT. Penelitian dilaksanakan pada bulan Januari hingga Juni 2018. Bahan uji ketahanan penyakit terdiri dari plantlet kentang koleksi Laboratorium PKHT IPB, bahan media MS, bahan sterilisasi, dan suspensi bakteri $R$. solanacearum koleksi dari Balai Besar Penelitian dan Pengembangan Bioteknologi dan Sumber Daya Genetik Pertanian (BB Biogen), Bogor. Genotipe kentang yang digunakan terdiri dari PKHT 4, PKHT 6, PKHT 9, PKHT 10, PKHT 12, Atlantik, Intan, Medians dan Granola yang dikategorikan sebagai kentang sayur atau industri menurut Harahap (2018). Atlantik dan Granola digunakan sebagai pembanding karena merupakan kultivar kentang yang paling banyak dibudidayakan petani saat ini. Rancangan percobaan yang digunakan dalam pengujian ketahanan terhadap penyakit layu bakteri adalah rancangan acak lengkap (RAL) satu faktor yaitu genotipe dengan 5 ulangan. Uji daya hasil menggunakan rancangan kelompok lengkap teracak (RKLT) satu faktor yaitu genotipe dengan tiga ulangan.

\section{Uji Ketahanan terhadap Penyakit Layu Bakteri secara In Vitro}

Persiapan bahan tanam sebagai materi percobaan uji ketahanan dimulai dengan perbanyakan stek in vitro menggunakan stek buku tunggal dari mother plant setiap genotipe yang akan diuji. Perbanyakan terus dilakukan sampai jumlah tanaman yang akan diuji terpenuhi. Tanaman kemudian diinkubasi dalam ruang kultur sampai berumur 42 hari setelah tanam (HST). Bahan inokulum bakteri didapatkan dari koleksi BB Biogen. Bakteri R. solanacearum diisolasi dari tanaman yang terinfeksi di lapangan, kemudian diperbanyak dalam media Sucrose Pepton Agar (SPA). Koloni bakteri selanjutnya diencerkan menggunakan akuades steril untuk mendapatkan suspensi bakteri dengan konsentrasi $1.2 \times 10^{8}$ koloni $\mathrm{mL}^{-1}$. Inokulasi tanaman dilakukan dengan teknik gunting yaitu memasukkan gunting ke dalam suspensi bakteri setiap kali akan digunakan untuk menggunting pucuk tanaman (Maharijaya et al., 2008). Plantlet diinokulasi setelah berumur 42 HST, lalu diinkubasi sampai muncul gejala infeksi bakteri $R$. solanacearum. Pengamatan meliputi karakter pertumbuhan tanaman di in vitro dengan cara mengukur tinggi tanaman, jumlah daun dan jumlah akar, periode inkubasi, kejadian penyakit yaitu persentase tanaman yang terinfeksi bakteri pada semua plantlet yang digunakan, dan ketahanan penyakit dengan cara mengkonversi persentase kejadian penyakit ke dalam derajat ketahanan menurut Mew dan Ho (1977), yaitu tahan jika tanaman yang terinfeksi kurang dari 20\%, agak tahan jika tanaman yang terinfeksi $20-40 \%$, agak rentan jika tanaman yang terinfeksi $40-60 \%$, dan rentan jika tanaman yang terinfeksi lebih dari $60 \%$.

\section{Uji Daya Hasil di Lapangan}

Persiapan lahan diawali dengan pembersihan lahan dari sisa pertanaman sebelumnya dilanjutkan dengan pembuatan bedengan berukuran panjang $3.5 \mathrm{~m}$, lebar $0.6 \mathrm{~m}$ dan lebar parit $0.15 \mathrm{~m}$. Pupuk kandang dengan dosis 15 ton $\mathrm{ha}^{-1}$ diberikan 2 minggu sebelum penanaman. Pupuk kendang ayam disebarkan di antara bedengan kemudian ditutup 
dengan tanah dari bedengan kiri dan kanan sehingga parit akan menjadi bedeng dan sebaliknya. Pembuatan lubang tanam dilakukan sebelum penanaman menggunakan tugal. Jarak tanam yang digunakan sebesar $75 \mathrm{~cm}$ x $25 \mathrm{~cm}$. Benih yang ditanam dalam tiap genotipe memiliki bobot antara $35-$ 42 g. Umbi yang digunakan sebagai benih telah mengalami pecah dormansi ditandai dengan munculnya tunas. Satu umbi ditanam per lubang dengan mata tunas menghadap ke atas kemudian ditutup dengan tanah. Pemeliharaan dilakukan sesuai prosedur operasional baku produksi kentang (Kementerian Pertanian, 2015). Penyiangan gulma dilakukan secara manual setiap dua minggu. Pengendalian hama dan penyakit dengan penyemprotan pestisida mulai tanaman berumur 21 HST sampai dengan 84 HST dalam rentang waktu 3 hari sekali. Hama Thrips palmi dikendalikan dengan insektisida berbahan aktif abamektin 2.2 $\mathrm{L} \mathrm{ha}^{-1}$, sedangkan lalat penggorok daun dikendalikan dengan Siromazin $7 \mathrm{~kg} \mathrm{ha}^{-1}$. Penyakit hawar daun (Phytopthora infestans) menggunakan fungisida berbahan aktif Klorotalonil $3.6 \mathrm{~kg} \mathrm{ha}^{-1}$, Simoksanil $3.6 \mathrm{~kg}$ $\mathrm{ha}^{-1}$, dan Mankozeb $7 \mathrm{~kg} \mathrm{ha}^{-1}$. Pemupukan susulan dengan NPK majemuk (15-15-15) dan SP-36 dengan dosis yang sama sebesar $650 \mathrm{~kg} \mathrm{ha}^{-1}$ dengan cara ditabur dalam lubang di dekat tanaman. Pembumbunan kedua dengan ketinggian $20 \mathrm{~cm}$ dari permukaan tanah dilakukan pada 40 HST. Pupuk Gandasil A (1.67 $\left.\mathrm{g} \mathrm{L}^{-1}\right)$ diberikan dengan cara disemprotkan pada 45, 60, dan 75 HST dengan dosis total $11 \mathrm{~kg} \mathrm{ha}^{-1}$. Penyemprotan pupuk Grandasil B $\left(2.5 \mathrm{~g} \mathrm{~L}^{-1}\right)$ pada $85 \mathrm{HST}$ dengan dosis $3.6 \mathrm{~kg} \mathrm{ha}^{-1}$.

Pemanenan dapat dilakukan setelah tanaman berumur 99-120 HST disesuaikan dengan waktu panen masingmasing genotipe. Tanaman siap dipanen ditandai dengan gejala daun menguning dan tanaman rebah. Satu minggu sebelum pemanenan dilakukan pemangkasan tajuk tanaman untuk menguatkan kulit umbi. Kegiatan panen dilakukan dengan menggali bedengan kemudian umbi diambil dan disimpan di pinggir bedengan selama sekitar satu jam untuk mengeringkan tanah yang menempel, kemudian umbi disusun dalam waring. Pengamatan meliputi persentase tanaman hidup, tinggi tanaman, diameter batang, jumlah daun, jumlah cabang pada 10 tanaman contoh pada setiap satuan percobaan, waktu berbunga, dan komponen hasil berupa jumlah umbi per tanaman, bobot tumbi per tanaman, dan produktivitas dengan cara mengkonversi bobot umbi per tanaman ke dalam satuan ton (dibagi 1,000,000) dikali dengan populasi tanaman dan persentase tumbuh. Populasi dengan jarak tanam $75 \mathrm{~cm}$ x $25 \mathrm{~cm}$ sebanyak 45,300 tanaman (Ambiya, 2017).

\section{Analisis Data}

Data yang diperoleh dari pengamatan dianalisis dengan uji F pada taraf nyata $\alpha=5 \%$. Uji lanjut Duncan Multiple Range Test (DMRT) dengan taraf nyata $\alpha=5 \%$, dilakukan pada peubah yang menunjukkan hasil uji berbeda nyata pada uji F. Perangkat lunak yang digunakan dalam seluruh proses analisis data meliputi Microsoft $\AA$ Office Excel 2010, Statistical Tool for Agricultural Research (STAR) versi 2.0.1 serta SAS University Edition.

\section{HASIL DAN PEMBAHASAN}

\section{Uji Ketahanan Penyakit terhadap Layu Bakteri secara In Vitro}

Analisis sidik ragam menunjukkan bahwa genotipe berpengaruh sangat nyata terhadap tinggi tanaman, jumlah daun dan jumlah akar (Tabel 1). Kondisi lingkungan dalam penelitian homogen yang tercermin dari nilai koefisien keragaman (KK) yang rendah, sehingga perbedaan tersebut diharapkan hanya dipengaruhi oleh perbedaan genotipe. Dari karakter pertumbuhan vegetatif, jumlah daun merupakan hal yang terpenting. Menurut Maharijaya et al. (2008) jumlah daun dapat menentukan kecepatan multiplikasi tanaman kentang. Hal tersebut dikarenakan jumlah daun menggambarkan jumlah buku yang berfungsi

Tabel 1. Nilai pengamatan tiga peubah vigor tanaman kentang in vitro pada 35 HST

\begin{tabular}{lccc}
\hline Genotipe & Tinggi tanaman $(\mathrm{cm})$ & Jumlah daun (helai) & Jumlah akar (akar) \\
\hline Atlantik & $7.43 \mathrm{a}$ & $11.5 \mathrm{~d}$ & $5.3 \mathrm{~b}$ \\
Granola & $5.40 \mathrm{~cd}$ & $13.4 \mathrm{ab}$ & $6.7 \mathrm{a}$ \\
PKHT 4 & $6.77 \mathrm{~b}$ & $13.8 \mathrm{a}$ & $5.2 \mathrm{bc}$ \\
PKHT 6 & $4.70 \mathrm{e}$ & $10.1 \mathrm{e}$ & $4.3 \mathrm{de}$ \\
PKHT 9 & $7.70 \mathrm{a}$ & $12.0 \mathrm{~cd}$ & $4.9 \mathrm{bc}$ \\
PKHT 10 & $5.80 \mathrm{c}$ & $8.2 \mathrm{f}$ & $4.1 \mathrm{e}$ \\
PKHT 12 & $4.83 \mathrm{de}$ & $10.0 \mathrm{e}$ & $4.1 \mathrm{e}$ \\
Intan & $6.70 \mathrm{~b}$ & $12.8 \mathrm{bc}$ & $4.3 \mathrm{de}$ \\
Medians & $5.70 \mathrm{c}$ & $11.2 \mathrm{~d}$ & $4.7 \mathrm{~cd}$ \\
KK (\%) & 6.09 & 4.42 & 6.11 \\
Uji F & $* *$ & $* *$ & $* *$ \\
\hline
\end{tabular}

Keterangan: Angka-angka yang diikuti huruf yang sama pada kolom yang sama tidak berbeda nyata pada uji DMRT taraf $\alpha=5 \%$, KK $=$ koefisien keragaman; ** berpengaruh sangat nyata, HST $=$ hari setelah tanam 
dalam perbanyakan tanaman kentang secara in vitro melalui stek buku tunggal (Purwito et al., 2017). Tinggi tanaman, jumlah daun, dan jumlah akar pada penelitian ini memiliki range tinggi tanaman, jumlah daun, dan jumlah akar pada beberapa penelitian pertumbuhan kentang in vitro (Karjadi dan Buchory, 2008; Setiawati et. al., 2018). Genotipe PKHT 4, PKHT 9, dan BM yang mempunyai jumlah daun relatif banyak diharapkan dapat membantu dalam proses pengadaan benih kentang yang lebih cepat. Genotipe yang memiliki tinggi tanaman tertinggi adalah Atlantik dan PKHT 9, sedangkan genotipe yang memiliki jumlah akar terbanyak adalah Granola, yaitu 6.7 akar per planlet. Tanaman yang memiliki jumlah akar yang banyak dapat mendukung pertumbuhan tanaman lebih vigor dan sehat, serta memiliki tingkat keberhasilan yang lebih tinggi pada saat aklimatisasi (Maharijaya, 2008).

Hasil analisis ragam menunjukkan genotipe berpengaruh sangat nyata terhadap periode inkubasi. Gejala infeksi yang muncul dalam penelitian ini dimulai dengan daun menguning hingga tanaman rebah, layu, dan mati. Penelitian Purwito dan Wattimena (2008) dan Maharijaya et al. (2008) pun menunjukkan gejala yang sama. Periode inkubasi dalam penelitian ini terjadi dalam rentang waktu 4.3-7.0 hari setelah inokulasi (HSI) seperti juga halnya pada penelitian Maharijaya et al. (2008) dan Habe (2018). Periode inkubasi yang diharapkan terjadi dalam rentang waktu lama, karena adanya korelasi yang sangat nyata negatif dengan ketahanan penyakit (Maharijaya et al., 2008). Periode inkubasi yang semakin lama maka tingkat kejadian penyakit tanaman semakin rendah.

Tabel 2 menunjukkan genotipe yang memiliki periode inkubasi tercepat terjadi pada 4.3-4.7 HSI diantaranya Granola, PKHT 6, PKHT 10, PKHT 12, Intan, dan Median. Periode inkubasi yang cepat pada beberapa genotipe tersebut mendorong persentase tingkat kejadian penyakit yang tinggi berkisar antara 66.7-100.0\%. Genotipe PKHT 4 dan PKHT 9 memiliki periode inkubasi yang berbeda nyata lebih lama dari semua genotipe, sehingga berimplikasi pada kejadian penyakit keduanya yang rendah. Periode inkubasi PKHT 4 dan PKHT 9 terjadi dalam waktu 6.3 dan 7.0 HSI dengan kejadian penyakit sebesar $33.3 \%$ dan $36.7 \%$ secara berurutan.

Kedua kultivar pembanding yang digunakan termasuk dalam kategori rentan dikarenakan jumlah tanaman yang terinfeksi di atas $60 \%$. Hal ini sejalan dengan hasil penelitian sebelumnya dimana secara konsisten kultivar Atlantik dan Granola rentan terhadap layu bakteri baik di in vitro maupun di lapangan (Maharijaya et al., 2008; Sofiari 2009; Taylor dan Dawson, 2021). Genotipe PKHT 4 dan PKHT 9 memiliki derajat ketahanan lebih tinggi dari kultivar pembanding dan termasuk ke dalam kategori tanaman agak tahan dengan persentase tanaman terinfeksi antara 33-36 \%. Diharapkan genotipe PKHT 4 dan PKHT 9 dapat menjadi sumber ketahanan dalam merakit kultivar unggul dengan tingkat ketahanan penyakit layu bakteri yang lebih tinggi dari kultivar komersial yang telah ada. Hasil pengujian secara in vitro diharapkan dapat mencerminkan tingkat ketahanan layu bakteri di lapangan (Maharijaya et al., 2008).

\section{Uji Daya Hasil di Lapangan}

Produktivitas Granola yang mencapai 30.31 ton $\mathrm{ha}^{-1}$ melebihi potensi hasil sebesar 26.50 ton $\mathrm{ha}^{-1}$ (SK Menteri Pertanian No. 444/Kpts/TP.240/6/1993). Hasil tersebut mengindikasikan penanaman dalam penelitian ini sudah sangat baik dan memberikan lingkungan tumbuh yang optimum. Hasil analisis ragam menunjukkan genotipe berpengaruh nyata terhadap beberapa komponen pertumbuhan, kecuali pada umur berbunga. Semua genotype kecuali Atlantik memiliki persentase tanaman hidup 100\%. Persentase tanaman hidup pada kultivar Atlantik rendah, hanya mencapai 50.0-70.0\% per satuan percobaan. Hal ini diduga akibat daya adaptasi kultivar Atlantik yang rendah

Tabel 2. Nilai pengamatan pada beberapa peubah ketahanan penyakit layu bakteri tanaman kentang in vitro

\begin{tabular}{lccc}
\hline Genotipe & Periode inkubasi (HSI) & Kejadian penyakit (\%) & Derajat ketahanan $^{\mathrm{a}}$ \\
\hline Atlantik & $5.7 \mathrm{bc}$ & $73.3 \mathrm{c}$ & $\mathrm{R}$ \\
Granola & $4.3 \mathrm{c}$ & $100.0 \mathrm{a}$ & $\mathrm{R}$ \\
PKHT 4 & $6.3 \mathrm{ab}$ & $36.7 \mathrm{e}$ & $\mathrm{AT}$ \\
PKHT 6 & $4.7 \mathrm{c}$ & $90.0 \mathrm{ab}$ & $\mathrm{R}$ \\
PKHT 9 & $7.0 \mathrm{a}$ & $33.3 \mathrm{e}$ & $\mathrm{AT}$ \\
PKHT 10 & $4.3 \mathrm{c}$ & $90.0 \mathrm{ab}$ & $\mathrm{R}$ \\
PKHT 12 & $4.3 \mathrm{c}$ & $100.0 \mathrm{a}$ & $\mathrm{R}$ \\
Intan & $4.7 \mathrm{c}$ & $73.3 \mathrm{c}$ & $\mathrm{R}$ \\
Medians & $4.3 \mathrm{c}$ & $66.7 \mathrm{~cd}$ & $\mathrm{R}$ \\
KK (\%) & 14.19 & 14.06 & - \\
Uji F & $* *$ & $* *$ & - \\
\hline
\end{tabular}

Keterangan: Angka-angka yang diikuti huruf yang sama pada kolom yang sama tidak berbeda nyata pada uji DMRT taraf $\alpha=5 \%$, KK $=$ koefisien keragaman, $* *$ berpengaruh sangat nyata, HSI $=$ hari setelah inokulasi, aderajat ketahanan menurut Mew dan Ho (1977), $\mathrm{R}=$ rentan; $\mathrm{AT}$ = agak tahan 
di Indonesia seperti dilaporkan pada beberapa penelitian sebelumnya yang berkisar antara 22-69 \% (Sofiari, 2009; Zulkarnaen et al., 2017).

Genotipe kentang IPB yang memiliki pertumbuhan tinggi tanaman melebihi semua genotipe adalah PKHT 6 dan PKHT 10, berbanding terbalik dengan PKHT 4, PKHT 9, dan PKHT 12 yang lebih rendah dibanding genotipe lainnya. Tinggi tanaman sebagian besar genotipe termasuk ke dalam kelas sangat pendek menurut UPOV (2004), kecuali PKHT 10 yang masuk ke dalam kelas pendek $(48.26 \mathrm{~cm})$ dan PKHT 6 termasuk kategori tinggi dengan rata-rata 55.20 $\mathrm{cm}$. Genotipe yang lebih baik untuk dibudidayakan adalah yang memiliki tinggi pendek-sedang, karena tanaman yang terlalu tinggi memerlukan pengikatan berkali-kali pada ajir agar tanaman tidak mudah roboh.

Diameter batang mempunyai peran penting dalam menopang tegaknya tanaman, sehingga tanaman diharapkan memiliki diameter dengan ukuran besar. Tabel 3 menunjukkan PKHT 6 mempunyai diameter berukuran $1.28 \mathrm{~cm}$ berbeda nyata lebih tinggi dari semua genotipe. Besarnya diameter pada genotipe PKHT 6 dan PKHT 10 dipengaruhi oleh bentuk tanaman keduanya yang tinggi.

PKHT 6 mempunyai jumlah cabang terbanyak. Selain itu PKHT 6 memiliki jumlah daun yang banyak mencapai 45.2 helai daun dan berbeda nyata lebih tinggi dari semua genotipe. Peningkatan jumlah cabang dapat meningkatkan jumlah daun. Jumlah cabang dan daun yang banyak diharapkan dapat meningkatkan fotosintat yang penting dalam proses produksi dan pembesaran umbi (Shubha dan Singh, 2018).

Berdasarkan hasil pengamatan pada Tabel 4 umur panen genotipe dapat digolongkan menurut Sastrahidayat (2011) menjadi tanaman berumur genjah (99 HST), sedang (106-107 HST), dan dalam (120 HST). Jumlah umbi per tanaman dari setiap genotipe pada Tabel 4 sangat beragam.
Sebagian besar genotipe menghasilkan lebih dari 5 umbi per tanaman, kecuali PKHT 4 dengan jumlah 4.3 umbi dan PKHT 9 sebesar 3.5 umbi. Genotipe dengan jumlah umbi terbanyak adalah Granola dan PKHT 6 pada jenis kentang sayur serta Medians dan PKHT 10 pada jenis kentang industri. Bobot per umbi lebih utama dibandingkan jumlah umbi per tanaman dalam budidaya kentang untuk konsumsi, berbeda jika ditujukan untuk budidaya produksi benih (Kusmana, 2012; Azhari, 2019). Menurut Kusandriani (2014) genotipe dengan karakter umbi per tanaman yang banyak dapat menguntungkan petani dalam pengadaan benih untuk pertanaman berikutnya.

Bobot umbi per tanaman yang tinggi merupakan hasil yang ingin dicapai dalam budidaya kentang. Genotipe PKHT 6 memiliki bobot umbi terbesar mencapai $870.26 \mathrm{~g}$ per tanaman, sehingga mendukung pencapaian produktivitas yang tinggi yaitu 38.91 ton $\mathrm{ha}^{-1}$ berbeda nyata lebih tinggi dibandingkan genotipe lainnya. Produktivitas PKHT 6 melebihi seluruh kultivar pembanding sehingga potensial untuk dilepas sebagai calon varietas unggul yang lebih baik bagi petani sebagai kentang sayur. Genotipe PKHT 10 menunjukkan hasil yang relatif tinggi yaitu bobot umbi per tanaman mencapai $634.62 \mathrm{~g}$ dan produktivitas 28.75 ton $\mathrm{ha}^{-1}$ melebihi Atlantik. Analisis sifat fisikokimia umbi kentang yang dilakukan oleh Harahap et al. (2018) menunjukkan PKHT 10 lebih unggul dari Atlantik sehingga direkomendasikan sebagai bahan baku keripik kentang, kentang goreng, dan mashed potato. Genotipe PKHT 10 dengan produktivitas dan sifat fisikokimia yang lebih unggul dari Atlantik, diharapkan dapat menjadi subtitusi yang lebih baik sebagai kentang industri.

Dalam penelitian ini belum didapatkan genotipe yang memiliki produktivitas tinggi yang tahan layu bakteri. Faktor ketahanan yang teridentifikasi pada genotipe PKHT 4 dan PKHT 9 dapat digunakan sebagai sumber ketahanan

Tabel 3. Nilai pengamatan pada beberapa peubah komponen pertumbuhan tanaman kentang

\begin{tabular}{lccccccc}
\hline Genotipe & $\begin{array}{c}\text { Persentase } \\
\text { tumbuh } \\
(\%)\end{array}$ & $\begin{array}{c}\text { Tinggi } \\
\text { tanaman } \\
(\mathrm{cm})\end{array}$ & $\begin{array}{c}\text { Diameter } \\
\text { batang } \\
(\mathrm{cm})\end{array}$ & $\begin{array}{c}\text { Jumlah daun } \\
(\text { helai })\end{array}$ & $\begin{array}{c}\text { Jumlah } \\
\text { cabang }\end{array}$ & $\begin{array}{c}\text { Umur } \\
\text { berbunga } \\
(\text { HST })\end{array}$ & $\begin{array}{c}\text { Kriteria } \\
\text { kentang }\end{array}$ \\
\hline Atlantik & $63.3 \mathrm{~b}$ & $28.06 \mathrm{~d}$ & $0.77 \mathrm{c}$ & $24.0 \mathrm{~b}$ & $2.4 \mathrm{~b}$ & 45.3 & Industri \\
Granola & $94.8 \mathrm{a}$ & $42.93 \mathrm{c}$ & $0.95 \mathrm{~b}$ & $14.9 \mathrm{c}$ & $0.5 \mathrm{~d}$ & - & Sayur \\
PKHT 4 & $97.4 \mathrm{a}$ & $18.86 \mathrm{e}$ & $0.75 \mathrm{~cd}$ & $13.4 \mathrm{c}$ & $0.7 \mathrm{~d}$ & 50.0 & Sayur \\
PKHT 6 & $98.7 \mathrm{a}$ & $55.20 \mathrm{a}$ & $1.28 \mathrm{a}$ & $45.2 \mathrm{a}$ & $5.7 \mathrm{a}$ & 47.6 & Sayur \\
PKHT 9 & $100.0 \mathrm{a}$ & $21.66 \mathrm{e}$ & $0.63 \mathrm{de}$ & $15.8 \mathrm{c}$ & $0.9 \mathrm{~cd}$ & - & Industri \\
PKHT 10 & $100.0 \mathrm{a}$ & $48.26 \mathrm{~b}$ & $0.95 \mathrm{~b}$ & $24.5 \mathrm{~b}$ & $2.0 \mathrm{~b}$ & 44.6 & Industri \\
PKHT 12 & $73.3 \mathrm{~b}$ & $19.40 \mathrm{e}$ & $0.61 \mathrm{e}$ & $14.2 \mathrm{c}$ & $0.4 \mathrm{~d}$ & - & Sayur \\
Intan & $94.8 \mathrm{a}$ & $39.73 \mathrm{c}$ & $0.92 \mathrm{~b}$ & $25.3 \mathrm{~b}$ & $1.9 \mathrm{~b}$ & 44.6 & Sayur \\
Medians & $97.4 \mathrm{a}$ & $42.73 \mathrm{c}$ & $0.96 \mathrm{~b}$ & $22.7 \mathrm{~b}$ & $1.8 \mathrm{bc}$ & 45.3 & Industri \\
KK $(\%)$ & 9.42 & 8.41 & 8.51 & 13.29 & 29.46 & & 11.47 \\
Uji F & $* *$ & $* *$ & $* *$ & $* *$ & $* *$ & tn & \\
\hline
\end{tabular}

Keterangan: Angka-angka yang diikuti huruf yang sama pada kolom yang sama tidak berbeda nyata pada uji DMRT taraf $\alpha=5 \%$ KK = koefisien keragaman, **berpengaruh sangat nyata, tn = tidak berpengaruh nyata, HST = hari setelah tanam. ${ }^{a}$ menurut Harahap (2018) 
Tabel 4. Pengaruh genotipe terhadap beberapa peubah komponen hasil tanaman kentang

\begin{tabular}{|c|c|c|c|c|c|c|}
\hline Genotipe & $\begin{array}{c}\text { Umur panen } \\
\text { (HST) }\end{array}$ & $\begin{array}{c}\text { Kelas } \\
\text { umur panen }\end{array}$ & $\begin{array}{c}\text { Jumlah umbi } \\
\text { per tanaman } \\
\text { (knol per tanaman) }\end{array}$ & $\begin{array}{c}\text { Bobot umbi } \\
\text { per tanaman } \\
\text { (g per tanaman) }\end{array}$ & $\begin{array}{l}\text { Produktivitas } \\
\quad\left(\text { ton } \mathrm{ha}^{-1}\right)\end{array}$ & $\begin{array}{l}\text { Kriteria } \\
\text { kentang }\end{array}$ \\
\hline Atlantik & 120.0 & Dalam & $6.88 \mathrm{~d}$ & $254.07 \mathrm{~cd}$ & $7.10 \mathrm{~d}$ & Industri \\
\hline Granola & 99.0 & Genjah & $11.54 \mathrm{a}$ & $705.77 b$ & $30.31 \mathrm{~b}$ & Sayur \\
\hline PKHT 4 & 107.0 & Sedang & $4.30 \mathrm{e}$ & $302.05 \mathrm{c}$ & $13.36 \mathrm{c}$ & Sayur \\
\hline РКНТ 6 & 120.0 & Dalam & $10.45 \mathrm{ab}$ & $870.26 \mathrm{a}$ & $38.91 \mathrm{a}$ & Sayur \\
\hline РКНT 9 & 106.0 & Sedang & $3.55 \mathrm{e}$ & $168.06 \mathrm{~d}$ & $7.61 d$ & Industri \\
\hline PKHT 10 & 120.0 & Dalam & $9.03 \mathrm{bc}$ & $634.62 b$ & $28.75 b$ & Industri \\
\hline PKHT 12 & 99.0 & Genjah & $7.79 \mathrm{~cd}$ & $172.22 \mathrm{~d}$ & $5.73 d$ & Sayur \\
\hline Intan & 106.6 & Sedang & $8.39 \mathrm{~cd}$ & $679.20 \mathrm{~b}$ & $29.03 b$ & Sayur \\
\hline Medians & 99.0 & Genjah & $8.11 \mathrm{~cd}$ & $592.71 b$ & $26.13 b$ & Industri \\
\hline KK (\%) & 0.17 & - & 13.49 & 12.75 & 12.50 & \\
\hline Uji F & $* *$ & - & $* *$ & $* *$ & $* *$ & \\
\hline
\end{tabular}

Keterangan: Angka-angka yang diikuti huruf yang sama pada kolom yang sama tidak berbeda nyata pada uji DMRT taraf $\alpha=5 \%$, KK $=$ koefisien keragaman, ${ }^{* *}$ berpengaruh sangat nyata, HST $=$ hari setelah tanam. ${ }^{2}$ Menurut Harahap (2018)

melalui persilangan dengan genotipe PKHT 6 dan PKHT 10 untuk mendapatkan calon varietas kentang yang berdaya hasil tinggi serta tahan layu bakteri.

\section{KESIMPULAN}

Genotipe kentang PKHT 4 dan PKHT 9 mempunyai tingkat ketahanan penyakit lebih tinggi secara in vitro dibandingkan kultivar pembanding, dengan tingkat ketahanan penyakit layu bakteri agak tahan. Kedua genotipe tersebut diharapkan dapat menjadi sumber ketahanan untuk merakit calon kultivar dengan ketahanan penyakit layu bakteri lebih tinggi dari kultivar. Genotipe kentang PKHT 6 memiliki produktivitas tertinggi mencapai 38.31 ton ha-1 mengungguli kultivar Granola dan Intan. Genotipe PKHT 10 memperlihatkan hasil baik dengan produktivitas sebesar 28.75 ton ha $^{-1}$ sebanding dengan Medians bahkan melebihi hasil Atlantik. Genotipe PKHT 6 dan PKHT 10 diharapkan dapat menjadi alternatif yang lebih baik sebagai kentang sayur dan kentang industri (berurutan) yang lebih unggul dari kultivar yang umum digunakan saat ini.

\section{DAFTAR PUSTAKA}

Ambiya, I. 2017. Panen dan pascapanen umbi konsumsi kentang (Solanum tuberosum L.) di Hikmah Farm, Pangalengan, Kabupaten Bandung, Jawa Barat. Skripsi. Fakultas Pertanian. Institut Pertanian Bogor. Bogor.

Azhari, A., A. Maharijaya, Sobir. 2019. Keragaan dan produksi umbi G2 kentang menggunakan sumber benih yang berbeda. J. Hort. Indonesia 10:27-35.
Habe, I. 2018. An in vitro assay method for resistance to bacterial wilt (Ralstonia solanacearum) in potato. Am. J. Potato Res. 95:311-316.

Harahap, S.E., Y.A. Purwanto, S. Budijanto, A. Maharijaya. 2018. Karakterisasi kerenyahan dan kekerasan beberapa genotipe kentang (Solanum tuberosum L.) hasil pemuliaan. J. Pangan 26:1-7.

Jolanda-Laisina, J.K., A. Maharijaya, Sobir, A. Purwito. 2021. The in vitro screening of drought tolerant potatoes (Solanum tuberosum L) of the center for tropical horticulture studies-IPB collections. JIPI. 26:235-242.

Karjadi, A.K., A. Buchory. 2008. Pengaruh auksin dan sitokinin terhadap pertumbuhan dan perkembangan jaringan meristem kentang kultivar Granola. J. Hort. 18:380-384.

[Kementan] Kementerian Pertanian. 2015. Standard Operasional Prosedur Produksi Benih Kentang (Solanum tuberosum).

[Kementan]KementerianPertanian. 2020. Data produktivitas kentang berdasarkan provinsi 2015-2019. http:// www.pertanian.go.id/ [18 Mei 2021].

Kusandriani, Y. 2014. Uji daya hasil dan kualitas delapan genotipe kentang untuk industri keripik kentang nasional berbahan baku lokal. J. Hort. 24:283-288.

Kusmana. 2012. Seleksi beberapa klon kentang (Solanum tuberosum L.) dari hasil persilangan untuk kerakter daya hasil tinggi pada ekosistem dataran tinggi di Ciwidey. Bul. Plasma Nuflah 18:45-53. 
Maharijaya,A., M. Mahmud, A, Purwito. 2008. Uji ketahanan in vitro klon-klon kentang hasil persilangan kentang kultivar atlantic dan granola terhadap penyakit layu bakteri (Ralstonia solanacearum) dan busuk lunak (Erwinia carotovora). J. Agron. Indonesia 36:133138.

Maharijaya, A., A.N. Salma, S. Amarilis. 2020. Produksi dan kualitas umbi beberapa genotipe kentang (Solanum tuberosum L.) koleksi IPB untuk olahan keripik kentang. J. Agron. Indonesia 48:275-282.

Maharijaya, A., M. Syukur, L.N. Salma, U.L. Sanubary. 2021. Diversity and performance of eight new promising potato (Solanum tuberosum) genotypes in Garut District, West Java, Indonesia. Biodiversitas 22:2848-2858.

Mew, T.W., W.C. Ho. 1977. Effect of soil temperature on resistance of tomato cultivars to bacterial wilt. Phytopathology 67:909-911.

Otieno, S.A., P. Collins, J. Coombs, C. Allen, D.S. Douches. 2021. Screening for Ralstonia solanacearum resistance in Solanum commersonii. Am. J. Potato Res. 98:72-77.

Purwito, A., G.A. Wattimena. 2008. Kombinasi persilangan dan seleksi in vitro untuk mendapatkan kultivar unggul kentang. JIPI 13:140-149.

Purwito, A., G.A. Wattimena, M. Syukur, F.I. Nuryana, H. Harti, A. Maharijaya. 2017. Evaluation of potato clones for their adaptation to medium altitude conditions in the tropics. Euphytica 213:1-8.
[Pusdatin] Pusat Data dan Sistem Informasi Pertanian. 2020. Impor komoditi pertanian berdasarkan kode HS. http://database.pertanian.go.id/ [29 April 2021].

Sastrahidayat, I.R. 2011. Tanaman Kentang dan Pengendalian Hama Penyakitnya. UB Press, Malang, ID.

Setiawati, T., A. Zahra, R. Budiono, M. Nurzaman. 2018. Perbanyakan in vitro tanaman kentang (Solanum tuberosum (L.) cv. Granola) dengan penambahan meta-topolin pada media modifikasi MS (Murashige \& Skoog). J. Metamorfosa 5:44-50.

Sofiari, E. 2009. Daya hasil beberapa klon kentang di Garut dan Banjarnegara. J. Hort. 19:148-154.

Shubha, K., D. Singh. 2018. Selection of yield-associated morphological and biochemical traits using correlation and path coefficient analysis in potato (Solanum tuberosum L.) in the foothills of NorthWestern Himalayas. Potato Res. 61:273-281.

Taylor, A.S., P. Dawson. 2021. Major constraints to potato production in Indonesia: a review. Am. J. Potato Res. $1: 1-16$

[UPOV] Internasional Union For The Protection Of New Varieties Of Plants. 2004. Guidelines for The Conduct of Tests for Distinctness, Uniformity and Stability Potato (Solanum tuberosum L.). UPOV, Geneva, $\mathrm{CH}$.

Zulkarnain, D.H., A. Maharijaya, M. Syukur. 2017. Uji daya hasil klon harapan kentang (Solanum tuberosum L) IPB di Kabupaten Garut Jawa Barat. Comm. Hort. J. 1:42-48. 